\title{
KERETA SINGO BARONG DI KERATON KASEPUHAN CIREBON
}

\author{
Sumino *)
}

\begin{abstract}
This study to look at the changes the meaning of Singo Barong in the context of the past as understood by the public Cirebon in the present. In the time, the train experienced a period of transit which to change the context in which the material or object of art will have meaning. As a result of the frequent occurrence of changes in the context of the meanings are often subject to change. It is an art object in transition, experiencing a change of meaning as a result of changes in context. Change of meaning will evoke an emotional response when crossing cultural boundaries.

Reading of documents or artifacts that are relevant necessary to achieve a deeper meaning and detail. Therefore anthropological perspective that links production and consumption of artifacts are not separated from the question of the culture, politics, religion and others. Borrowing the theory of "processual relativism" Svasek will bring an understanding of the art material in a different time and space. At least not with borrowed this theory will be obtained the values behind the train characteristics. By finding the characteristics at a certain time and space will be acquired meaning, then what meaning it will be reviewed and compared. Such way of thinking is more easy to see the socio-cultural change at both the pattern of thought or social institutions Kasepuhan Cirebon palace.

Singo Barong train its existence is equivalent to other objects stored in the Museum Kasepuhan Cirebon, such as gamelan, batik cloth, weapons, and so forth. Artifacts have the same weight value when used as a tool in the ritual. But the context has a different meaning, is associated with the constituent. From time to time, the meaning is changed, both in social and cultural areas. Religious meaning at the time of the kings was in power changed the fulfillment of the ritual or ceremonial, then change as the fulfillment of the economy and tourism.
\end{abstract}

Keywords: Train Singo Barong, Svasek, Changes

\section{LATAR BELAKANG}

Kereta yang ditarik oleh kuda, sapi ataupun kerbau pada umumnya dipahami oleh masyarakat sebatas sarana transportasi atau alat angkut hasil-hasil pertanian maupun perkebunan, oleh karenanya variasi dari alat angkut tradisional ini beragam antara lain dokar, andong, cikar, kereta perang, kereta kuda, atau kereta kencana. Beragamnya kereta tersebut akan berubah nilai dan fungsinya apabila kereta itu diletakkan dalam ruang pameran, galeri, museum, tempat keramat, tempat pemujaan, arena sirkus, keraton dan sebagainya.

Di keraton Kasepuhan Cirebon terdapat kereta yang diukir berbentuk hewan aneh dan langka, bahkan hewan semacam itu tidak dijumpai di alam ini. Masyarakat Cirebon menyebutnya kereta Singo Barong. Digagasnya kereta tersebut merupakan upaya Sultan untuk kepentingan upacara Kirab dan upacara Penobatan Raja, sehingga derajatnya tidak sama sebagaimana kereta yang dibayangkan oleh

*) Sumino (suminopak@yahoo.com), Staf Pengajar Program Studi Kriya Seni, Jurusan Kriya, Fakultas Seni Rupa, Institut Seni Indonesia Yogyakarta. 
masyarakat petani ataupun masyarakat pada umumnya.

Ciri-ciri ukiran hewan aneh itu memberikan gambaran pada masyarakat bahwa konstruksi kebudayaan Cirebon di masa silam terbentuk dari tiga kekuatan besar, yakni kebudayaan Cina, India, dan Mesir. Penyatuan ketiga kebudayaan tersebut kemudian diwujudkan dalam bentuk kereta kebesaran raja berukirkan makhluk Prabangsa, ${ }^{1}$ bercampurnya budaya antar negara itu kemudian menjadi identitas "Budaya Caruban". Kata caruban itu sendiri mengandung makna campuran yang kemudian oleh masyarakat Cirebon kata Caruban itu lama kelamaan dirubah ucapan menjadi Cirebon (Argadikusuma, tt: 9).

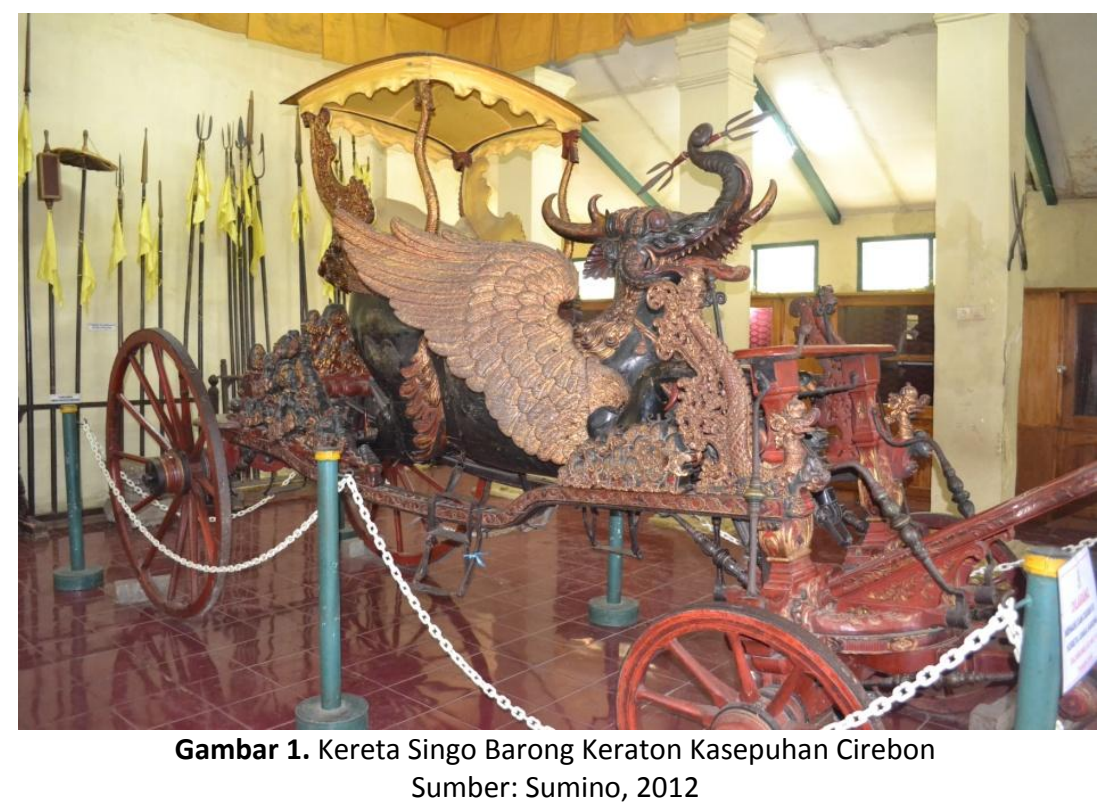

Kereta Singo Barong merupakan suatu fenomena menarik, terutama pada wujud fisiknya bila dikaitkan dengan ilmu seni kriya. ${ }^{2}$ Kereta ini nampak unik, baik bentuk, konstruksi, tata warna maupun ukirukirannya. Ciri-ciri yang diamati akan menuntun masyarakat dalam memahami konteks kereta Singo Barong, bahkan sampai pada persoalan budaya, politik, kekuasaan, agama, dan sebagainya. Sejak kemunculannya hingga sekarang kereta Singo Barong telah mengalami transisi dari generasi satu ke generasi berikutnya. Implikasinya, simbol kebesaran, simbol kekuasaan, dan kepentingan-kepentingan politik, budaya, dan agama mengalami perubahan.

Ukiran Naga, Mega Mendung, dan warna merah keemasan pada kereta Singo
Barong mengingatkan kepada ukir-ukiran gaya Cina dan peran-peran masyarakat Cina di Cirebon waktu itu, sedang di bagian ukiran belalai Gajah yang melilit senjata Trisula mengingatkan peran-peran penting kaum Hindu India kaitannya dengan keberadaan tiga Dewa (Argadikusuma: tt: 8).

Dapat dilihat bagaimana pengaruh Hindu-Budha, Cina, Islam berkembang berdampingan di samping tetap merawat dan membesarkan budayanya sendiri. Pengaruh-pengaruh itu menyatu yang kemudian membentuk struktur budaya khas, mulai dari kain batik, seni pertunjukan, seni ukir sampai seni arsitektur. Demikian pula sistem kepercayaan masyarakatnya, sekalipun Sunan Gunung Jati telah menjadikan Islam 
sebagai basis religi, tetapi apabila kita cermati lebih seksama, budaya Islam dan Hindu bercampur menjadi bagian adat masyarakat Cirebon. Hal-hal semacam itu perwujudannya dapat dilihat pada berbagai peristiwa keadatan, seperti dalam upacara adat Ngunjung, Nyadran, Bancakan, Mapag Sri, Bubarikan, sedekah Bumi (Dede Wahidin, 2003).

Kereta Singo Barong merupakan bagian dari kebudayaan khas Cirebon, kemunculannya digunakan sebagai kontrol sosial di tengah masyarakat multietnis, oleh karenanya muncul dugaan-dugaan apakah Singo Barong merupakan simbol kebesaran, pembeda status sosial, simbol kekuasaan raja, simbol penyatuan antar kekuasaan, ataukah merupakan resistensi terhadap kekuasaan.

\section{KERANGKA TEORI}

Objek kajian berdasarkan pada dokumen-dokumen tertulis, artefak, dan informasi yang disampaikan oleh informan sebagai pijakan untuk menentukan dugaan awal. Pembacaan lewat dokumen ataupun artefak merupakan cara kajian yang relevan agar dicapai data yang lebih dalam dan rinci, oleh karena itu dalam tulisan ini menggunakan teori perspektif antropologi pada seni yang ditulis oleh Maruska Svasek. ${ }^{3}$ Svasek mendefinisikan seni sebagai proses sosial, mempelajari tidak hanya artefak itu sendiri dan nilai-nilai dikaitkan dengan masyarakat, tetapi juga proses produksi dan konteks yang lebih luas. Memberikan gambaran kritis teori antropologi berbagai seni, Svasek menawarkan perspektif baru yang berpusat pada analisis komoditisasi, aestheticisation dan lembaga objek.

Svasek berpendapat, perspektif antropologi yang menghubungkan produksi dan konsumsi artefak tidak lepas pula dari persoalan proses budaya politik, agama dan lainnya. "Anthropology, Art and Cultural Production" memberikan gambaran rinci tentang tema yang penting bagi bidang sejarah seni, sosiologi seni dan studi budaya. Svasek menanggapi pertanyaan klasik dari apa yang dianggap merupakan objek seni dan menolak definisi sebelumnya yang mendefinisikan seni dalam batas-batas budaya. Svasek berpendapat bahwa menggunakan "relativisme prosesual" akan membawa pemahaman definisi suatu material seni pada waktu dan ruang yang berbeda, kemudian perkara tersebut disebut sebagai proses transit dan transisi.

Terjadinya transit akan melahirkan perubahan-perubahan konteks dimana material atau objek seni akan memiliki makna. Sebagai akibat dari sering terjadinya perubahan konteks maka makna sering pula mengalami perubahan. Hal ini objek seni mengalami masa transisi, mengalami perubahan makna sebagai akibat dari perubahan konteks. Perubahan makna akan membangkitkan respons emosional saat melintasi perbatasan budaya. Svasek juga melihat pada kriteria definisi seni lain yang dikaitkan "pasar". Tema-tema seperti itulah merupakan sifat transisi seni dan bagaimana persepsi itu berubah menurut waktu, tempat dan budaya ( Svasek, 2007: 4 ).

\section{BUKTI TERTULIS DAN ARTEFAK}

Kereta yang ditarik oleh kuda ataupun kerbau merupakan alat angkut yang belum bisa dipastikan kapan munculnya. Pada masa pra sejarah di Indonesia kereta belum pernah ditemukan, tetapi keberadaan roda diduga muncul pada masa bercocok tanam, berkaitan erat dengan digunakannnya alat roda tersebut di dalam produksi alat-alat yang terbuat dari tanah liat (gerabah). Pada masa bercocok tanam, manusia telah menunjukkan tandatanda hidup menetap. Pada masa seperti itu manusia telah pula mengembangkan penghidupan baru berupa budidaya tanaman dalam tingkat sederhana dan penjinakan binatang-binatang tertentu untuk dipelihara. Hal semacam ini juga menimbulkan dugaan bahwa pada masa itu 
telah dikenal alat angkut yang telah menggunakan roda dan ditarik oleh binatang kerbau, sapi, atau kuda (Wardana, 1990:1-2).

Informasi tentang adanya alat angkut yang menggunakan roda dapat ditemukan pada relief candi Borobudur, Prambanan, dan naskah kesusastraan. Sumber tertulis dari naskah kesusasteraan terdapat pada ceritera Ramayana dan Mahabarata dalam pewayangan. Relief Candi Borobudur yang menggambarkan kereta antara lain terdapat pada bagian cerita Lalitavistara (cerita tentang kehidupan Sidharta Gautama). Gambaran tentang kereta di dalam Candi Prambanan terdapat pada relief cerita Ramayana.

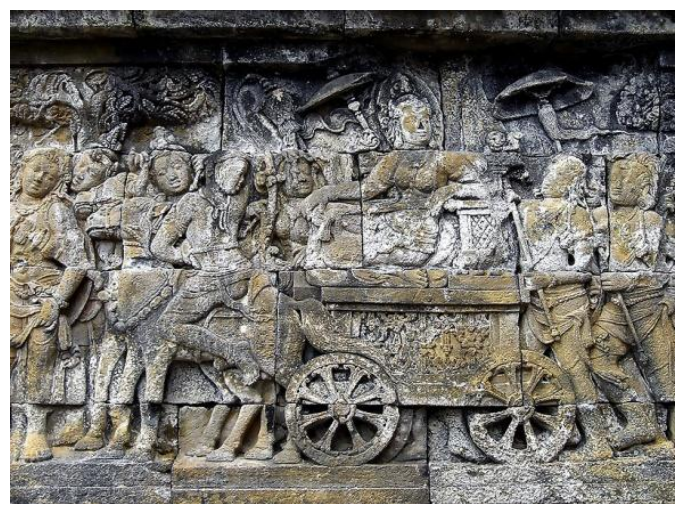

Gambar 2. Relief kereta pada candi Borobudur mengisahkan ratu Maya mengendarai kereta yang kemudian melahirkan Sidharta Gautama Sumber: gaptekupdate.com,2011

Relief pada candi-candi dan berita-berita tertulis dalam kesusasteraan ${ }^{4}$ menjelaskan bahwa kereta digunakan pada fungsi-fungsi kehormatan di kalangan kastaistik "tertinggi" seperti para bangsawan, para ningrat, para kesatria, dan tidak ditemui di wilayah kaum bawah atau rakyat jelata.

Karya sastra dan seni rupa di candicandi ini merupakan realita yang bisa ditemukan sekarang. Namun sulit diduga, apakah karya tersebut merupakan realita kehidupan masyarakat masa itu, ataukah itu merupakan kepiawaian seniman dalam merekayasa gagasan di bawah frame hirarki raja-raja di Jawa yang tidak mau melepaskan identitas sebagai kelompok tersendiri dan berpranata khusus. Penguatan identitas merupakan "strategi" para raja zaman dulu agar klasifikasi kastaistik tetap terpelihara sepanjang kekuasaan, masyarakat akan mudah dikendalikan dalam menata hubungan sosial kaum "elite" dan kaum "bawah".

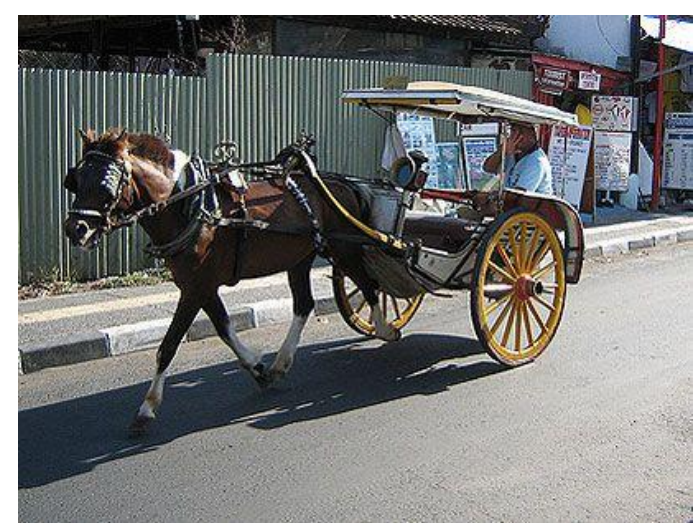

Gambar 3. Andong, merupakan generasi dari delman ${ }^{5}$, Sumber: utamieka.wordpress.com

Kehadiran kereta di masa sekarang merupakan "revolusi" alat angkut dari masa kolonial terkait dengan kemajuan jaringan jalan akibat dari penebasan hutan pada awal abad ke-19 (Denys Lombard, 200: 134). Setelah diketemukan kendaraan mesin, sebagian masyarakat mulai beralih, tetapi di beberapa daerah masih menggunakan tenaga manusia meskipun kereta yang ditarik oleh binatang sudah tidak terhitung jumlahnya.

Kereta pada awalnya digunakan sebagai alat transportasi, alat angkut hasilhasil pertanian, hasil-hasil hutan, ataupun binatang buruan. Oleh karena pengaruh kuat dari kolonial di kalangan bangsawan, lahirlah gaya hidup apa yang sekarang disebut dengan Westernisasi atau pembaratan $^{6}$ kendaraan. Sekarang fungsi kereta bukan lagi sekadar alat angkut, melainkan sudah merupakan bagian dari "regalia" para raja di Jawa, kereta-kereta 
semacam itu kemudian menjadi kesukaan dan kebanggaan beberapa kerajaan seperti Kasultanan Cirebon, Kasultanan Yogyakarta, Kasunanan Surakarta, Kadipaten Mangkunegaran, dan Kadipaten Paku Alaman.

Temuan diskriptif di atas, bila dianalisis menggunakan teori relatifisme Svasek akan memberikan pemahaman tentang kereta dari berbagai konteks. Bahwa pemahaman kereta Singo Barong pada waktu-waktu tertentu, fase-fase tertentu, dan tempat-tempat tertentu akan ditafsirkan secara berlainan. Ruang dan waktu sangat menentukan dalam memberi makna, oleh karena itu di sinilah kontek kereta akan mendapat makna.

Realitas dalam kehidupan, konteks kereta sebagai sarana transportasi di beberapa pedesaan terpelosok masih ditempatkan sebagai alat angkut yang penting. Di beberapa pedesaan di Cirebon masih bertahan dengan tenaga manusia atau tenaga binatang sebagai penggerak alat angkut sederhana. Mereka memilih keseran sebagai alat angkut sederhana meskipun kereta yang ditarik oleh kuda tidak sedikit jumlahnya, apalagi mobil colt, truk dan sejenisnya.

\section{KERETA SINGO BARONG DALAM KONTEKS RITUAL}

Arti ritual terkadang berbeda-beda, bisa diartikan dengan upacara keagamaan, seperti churh ritual (upacara kegerejaan) yang sifatnya pembekalan kerohanian dengan capaian kedamaian, ritual dance (tari keagamaan) dalam capaiannya mengarah kepada kesejahteraan (Widaryanto, 2007:22 ). Ritual bisa dimaknai sebagai suatu tindakan upacara keagamaan, eksistensinya sering dikaitkan dengan nilai simbolik, capaiannya pada umumnya ditentukan oleh suatu agama atau oleh tradisi masing-masing. Suatu ritual keagamaan dilakukan pada waktu yang tertentu, atau pada kesempatan yang lebih spesifik. Mungkin saja dilakukan oleh individu dengan suatu kelompok, antara kelompok satu dengan kelompok yang lain, atau oleh komunitas tertentu di tempattempat yang dipilih.

Ritual sifatnya terbatas pada tindakan masyarakat tertentu, atau antar lintas kepentingan sosial dan kepentingan religius di suatu negara. Tujuan ritual agama sangat bervariasi, terkadang meliputi pemenuhan suatu kewajiban religius yang ideal sebagai pemenuhan rohanian, kepuasan dari kebutuhan emosional, memperkuat ikatan sosial, demonstrasi atas kehormatan, menyatakan keanggotaan seseorang, atau terkadang hanya untuk kesenangan upacara agama sendiri. Para ahli filsafat, mulai dari Rousseau hingga Herbert Spencer, Durkheim menjelaskan bahwa ritual-ritual yang melintasi generasi, dari primitif hingga masyarakat sekarang pada dasarnya dilaksanakan guna memahami kehidupan sosial (Pricthard:1983, 2).

Berbagai macam ritual merupakan suatu corak yang hampir ada disemua masyarakat masa lampau atau kini. Tidak hanya meliputi berbagai upacara pemujaan dan sakramen, tetapi juga ritus sumpah kesetiaan, penobatan, dan pelantikan atau peresmian pengukuhan presiden, perkawinan, dan pemakaman. Tetapi tradisi sekolah seperti wisuda, kenaikan pangkat dan derajat, pawai Veteran, Belanja Natal dan sebagainya merupakan corak ritual. Para ahli antropologi menemukan berbagai ritual keagamaan di belahan bumi di setiap kultur masyarakat yang berbeda. Dalam ritual keagamaan, unsur paling mendasar adalah variasi antar budaya, isi dan fungsi sosial sering menampakkan hal yang dominan. Corak ritual yang ada di Keraton Cirebon sangat beragam, masing-masing ritual memiliki konsep yang bermacam pula. Konsep-konsep tersebut bertujuan menemukan pemahaman sosial lintas generasi. Ritual-ritual yang berlangsung 
hingga kini nampaknya mewarisi ritual-ritual era para wali bahkan ada beberapa konsep mengacu zaman sebelum para wali.

"Jamasan" atau memandikan Kereta Singo Barong merupakan sala satu corak ritual di antara sekian banyak ritual di keraton Kasepuhan. Sehabis dimandikan, kereta kemudian dimasukkan kembali dalam ruang museum. Setiap hari ruangan kereta Singo Barong berbau menyengat aroma dupa dan bunga. Masyarakat yang percaya, melemparkan uang serta mengusap benda-benda pusaka itu dengan kain, kemudian diusapkan kain itu ke wajah, tujuannya tidak lain agar mendapat berkah dari kekuatan kereta tersebut. Konteks kereta dalam fenomena ritual ini kemudian dianggap memiliki "roh", sebagai media komunikasi yang menghubungkan antara manusia dengan kekuatan roh tersebut.

Pada prosesi ritual pernikahan kerabat keraton, kereta Singo Barong tidak lagi memiliki "kekuatan" seperti yang ditunjukkan pengunjung dalam ritual "jamasan", melainkan hanya sebagai kendaraan tanpa makna apapun. Kedua peristiwa ritual tersebut bisa dipahami bahwa kereta "Singo Barong" terkadang berperan sebagai simbol, sebagai sesuatu yang telah dimaknai, tetapi di suatu ritual tertentu kereta "Singo Barong" hanya sebatas media teks. Sebagaimana teori semiotik Roman Jakobson, bahwa teks ini menekankan pada kemampuan karya seni itu sendiri di dalam mencerminkan dunia nyata atau kenyataan sosial, politik, ataupun ekonomi. Atau menekankan kodrat karya seni sebagai struktur yang otonom, bahwasanya seni tidak membutuhkan halhal lain di luar dirinya. Bila ingin melihat konteks maka diperlukan teks, dan guna menyusun sebuah makna diperlukan perhatian terhadap tanda dan simbol (Budiman, 2003:11).

Ketika kereta dilihat sebagai teks, posisinya menempati nilai fungsi pemenuhan material, jauh dari nilai-nilai simbol dengan berbagai interpretasi yang melekat padanya. Tetapi ketika diletakkan dalam konteks ritual maka terjadi perubahan nilai dan cara pandang. Nilai-nilai yang muncul tidak lain dibentuk dari korelasi teks dengan konteks. Bila mengikuti paradigma Kuhn, perubahan terjadi pada tataran metodologis yaitu perubahan dari pendekatan fungsional menuju kepada pendekatan interpretasi guna mengungkapkan sistem simbolik dan sistem makna.

\section{KERETA SINGO BARONG DALAM KONTEKS KERAJAAN}

Masih ingat dalam sejarah, di zaman kerajaan Hindu raja memerlukan legitimasi sebagai keturunan dewa, bahkan sesekali diakui sebagai titisannya. Karena sama-sama memperkuat legitimasi, raja akan mendukung bahkan menggabungkan dua agama. Itulah yang terjadi dengan agama Hindu dan Buddha. Tidak jarang raja minta diakui sebagai titisan dewa. Contohnya Kertajaya raja Kediri, yang menuntut agar rakyat menyembahnya sebagai Batara Guru, begitu pula Ken Arok yang menggulingkan Kertajaya di tahun 1222 (Simbolon, 2000).

Raja dipandang sebagai keturunan dewa atau dewa-raja, dengan memiliki ciriciri dan sifat magis, keramat dan bahkan merupakan pusat dari alam semesta di kalangan wilayah kerajaan. Di Jawa kita menemukan banyak bangunan candi yang megah tempat raja-raja keramat yang meninggal dunia disemayamkan. Lain dengan Sriwijaya di Sumatra, sebagai negara pantai yang hidup dari perdagangan, segala potensi dan kekuatan rakyatnya diarahkan ke arah teknologi membangun perahuperahu untuk armada perdagangan, sehingga tidak kerap ditemukan asesorisasesoris atau atribut raja (Koentjaraningrat, 1971: 23).

Kebesaran dan legitimasi raja terkadang ditunjukan dengan berbagai asesoris, apakah itu pusaka, kendaraan, 
busana, tempat tinggal dan sebagainya. Tetapi lahir pula dari integrasi antara pemerintahan kerajaan dan agama, ini merupakan unsur penting mengingat fungsi agama dalam masyarakat. Kalau para pembesar negara mewakili satu golongan di masyarakat, agama cenderung mewakili seluruh lapisan masyarakat yang sifatnya non-golongan dan non-kelas. $\mathrm{Hal}$ ini menyebabkan kerajaan-kerajaan tradisional mencari legitimasi (Onghokham, 1983: 94). Maka secara sepintas kereta Singo Barong dibangun dari kaidah-kaidah budaya yang menyerukan pentingnya agama di dalam menata masyarakat. Sehingga kereta tersebut tidak dilihat sebelah sebagai kepentingan raja semata melainkan lebih kepada kepentingan berbagai lapisan masyarakat. Namun demikian kereta selalu melekat sebagai tanda kebesaran raja di sela-sela kepentingan sosial, agama, dan budaya dalam bentuk apapun.

\section{KERETA SINGO BARONG DALAM KONTEKS MITOLOGI}

Fisik kereta "Singo Barong" sangat berbeda bila dibanding dengan keretakereta sejenis di beberapa keraton di Jawa. Perbedaannya terletak pada bentuk, sentuhan ahli ukir dan garapan arsitek yang piawai. Sehingga kereta tersebut nampak agung dan mempesona, bahkan nilai-nilai sejarah yang mendasari kemunculannya itu sangat mencolok. Selain berbeda pada tingkat wujud, kereta "Singo Barong" memiliki perbedaan pula di tingkat filsafat.

Pada tingkat wujud bisa diamati keindahan-keindahan ukiran, kehalusan garapan, konstruksi, penempatan ornamen dan tata warna yang menawan. Sedangkan ditingkat filsafat bisa diamati dibalik ciri-ciri ukiran, tata warna, asal-usul, sejarah, dan tindakan-tindakan spiritual terhadap kereta tersebut. Tindakan-tindakan spiritual itu menjadikan kereta "Singo Barong" memiliki kekuatan magis.
Bukan sebatas ciri fisik yang bisa digunakan untuk membenarkan anggapan melainkan sudah sampai kepada tindakan simbol. Sebab melalui simbolisme ini dunia filsafat dan mistisisme menjadi sangat dekat dengan realita.

Jika simbol diyakini sebagai alat untuk mendekatkan antara dunia filsafat dan mistis dengan realita, maka gagasan Peter L. Berger tentang simbol sebagai usaha setiap masyarakat untuk melembagakan pandangan atau pengetahuan mereka tentang masyarakat, di mana dibangun suatu dunia arti simbolik yang universal, yang kita namakan pandangan hidup atau ideologi. Dengan memandang masyarakat sebagai proses yang berlangsung dalam tiga momen dialektis yang simultan itu; internalisasi, eksternalisasi dan obyektivasi, maka yang kita namakan kenyataan sosial itu merupakan suatu konstruksi sosial buatan masyarakat sendiri dalam perjalanan sejarahnya dari masa silam, ke masa kini dan menuju masa depan (Berger, 1990: xxiiixxiv).

Bila di dalam memahami kereta "Singo Barong" harus mensyaratkan pelembagaan pandangan ideologi masyarakat, maka unsur-unsur yang terkait mesti ditarik ke wilayah prosesi dialektis internal, ekternal, dan obyektivasi yang tidak jauh dari peristiwa-peristiwa sosial yang terjadi pada masyarakat Cirebon, agar diperoleh kenyataan yang di bangun oleh masyarakat itu sendiri. Lebih lanjut gagasan mengenai simbol dikatakan oleh Turner bahwa mengkaji melalui simbol akan ditemukan pemilik kebudayaan dan pewaris kebudayaan di generasi-generasi berikutnya. Sebab simbol bukanlah hal yang jauh dari jangkauan masyarakat, melainkan sesuatu yang mereka kenal dan pahami, karena selalu mereka temukan dalam kehidupan sehari-hari (Abdullah, 2002:4). Jika demikian maka mengenali dan memahami peristiwa-peristiwa sosial sejak 
kereta "Singo Barong" digagas bahkan sebelum kereta tersebut digagas, merupakan prosesi yang harus dilembagakan pula kepada generasi sekarang.

Bila diamati bentuk kepala kereta tersebut adalah "naga" bertanduk rusa, dan berbelalai gajah melilit senjata Trisula. Relevansi bentuk "naga" diduga terkait dengan pentingnya atas pengaruh-pengaruh Cina terhadap kebudayaan dan kehidupan sehari-hari orang Jawa. Bagaimana orang Cina meningkatkan kenyamanan hidup "un sens de confort" dengan berbagai cara dan gaya tersendiri, yang sering diambil alih dalam bentuk dan takaran yang berbedabeda oleh masyarakat Jawa (Lombard, 2000: $\mathrm{xx}$ ).

Naga dipahami oleh masyarakat Cina sebagai lambang kesuburan atau binatang pembawa berkah. Binatang mitologi ini selalu digambarkan memiliki kepala singa, bertaring serigala dan bertanduk menjangan. Tubuhnya panjang seperti ular dengan sisik ikan, tetapi memiliki cakar mirip elang. Sementara Singa dalam masyarakat China merupakan simbol penolak bala, yang di masa sekarang menjadi salah satu ciri kebudayaan Cina dalam seni pertunjukan "Barongsai". Barongsai dianggap mendatangkan kebaikan, kesejahteraan, kedamaian, dan kebahagiaan.

Pada bagian samping depan di diletakkan pula dua "naga" bermahkota. Berbeda dengan gambaran naga style Cina, naga ini diduga mengandung anasir Hinduistis. Ciri yang memperkuat dugaan itu terdapat pada gaya ekornya yang selalu ditempatkan lebih tinggi, lebih nampak lagi pada mahkota yang selalu dikaitkan dengan mahkota kemaharajaan para raja Hindu.

Trisula dipahami sebagai senjata milik dewa. Sebagai simbol pula oleh penganut kitab Tripitaka guna merujuk adanya tiga dewa (Brahma, Wisnu, dan Siwa) yang disebut dengan Tri Murti, merupakan manifestasi adanya kekuasaan wyapi wyapaka nirwikara, kekuasaan Tuhan Yang Maha Esa yang menguasai seluruh ruang dan waktu yang ada di alam raya ( Sukanadi, 2002: 111). Kemudian simbol "trisula" diadopsi sebagai perayaan atas tercapainya perpaduan budaya dari ketiga kebudayaan (Hindhu, Budha, dan Islam). Trisula memiliki makna sangat dangkal bila dikaitkan dengan arti kata, Tri = tiga, Sula = Tajam. Tetapi dalam konsepsi Hindu-Jawa memuat falsafah yang ditujukan kepada masyarakat dalam mengolah batin lewat spiritual guna mencapai "tajamnya alam pikiran manusia " yaitu menghidupkan daya cipta, rasa dan karsa. Bagian Badan dari kereta ini berbentuk binatang kuda bersayap, oleh umat Islam dinamakan Buraq, tetapi sulit dikelompokkan ke dalam spesies binatang tertentu. Binatang rekaan ini telah menarik simpatisan dikalangan masyarakat Islam, menjadi bagian topik yang menarik bagi Katherine di dalam mengkaji Buraq sebagai kuda Imam Husein as (Iqbal, 2006: 114). Buraq diyakini sebagai kuda Rasulullah dan Imam Husein as. Hal ini karena Buraqlah yang membawa ruh suci Imam Husein ke sisi Allah Swt setelah meninggal syahid di padang Karbala. Kekuatan lambang ini berpengaruh tidak saja di masa-masa konflik kerajaan Cirebon waktu itu, tetapi saat sekarang menjadi ikon sebuah perusahaan penerbangan komersial "Buraq Air Line" meskipun pada akhirnya perusahaan ini tutup.

Mitologi Buraq di kalangan Islam senantiasa dikaitkan dengan keteladanan Nabi ketika hijrah menuju langit lapis tujuh. Pemahaman ini sulit dimengerti pada realitanya, tetapi di kalangan masyarakat Islam memiliki konsepsi yang dikemas dalam rukun "iman" yang salah satu dari rukun "iman" tersebut adalah percaya terhadap Nabi dengan segala tindakannya.

Bagian tutup belakang terdapat ukiran yang mengambil motif "wadasan", stiliran batu padas yang konon dibawa oleh 
putri Ong Tien Nio dari negeri Tiongkok. Ada yang menduga batu padas ini dipakai sebagai bahan campuran membuat keramik Cina, kebenaran ini perlu diteliti kembali. Motif wadasan di kemudian hari menjadi motif khas Cirebon, yang pengaruhnya sampai kepada kain batik, keramik, tatah kulit sungging, dan ukiran kayu. Sebagian masyarakat mengidentifikasi motif ini sama dengan motif "mega mendung" yang terkenal itu, meskipun terdapat perbedaan. Mega Mendung berada di wilayah atas, sedangkan wadasan berada di wilayah bawah. Bentuknya sama tetapi "wadasan" sesekali tumbuh tanaman menjalar, kiranya ini menjadi pembeda. Motif "wadasan" dapat ditemukan pada bangunan Sunyaragi, juga pada komplek tamansari keraton Kasepuhan Cirebon.

Kereta "Singo Barong" memiliki roda berjumlah empat. Dua roda bagian belakang lebih besar ukurannya dibanding dengan dua roda yang ada dibagian depan. Roda-roda bagian belakang diperkuat dengan ruji-ruji dari kayu berjumlah duabelas, dan sepuluh pada roda depan. Ruji-ruji kayu ditata melingkar mengikuti bingkai lingkaran kemudian menuju titik tengah sebagai pusat. Kekuatan roda selain ditopang oleh ruji-ruji yang menghubungkan ke poros, diperkuat pula oleh besi melingkar dibagian luar roda. Bila dikaitkan dengan kerajaan Jawa yang menganut aliran konsentris, maka diinterpretasikan sebagai upaya mengkultuskan serta memantapkan kekuasaan yang terpusat di keraton.

Interpretasi terhadap roda kereta "singo barong" ke dalam kerangka kekuasaan konsentris itu lebih relevan bila dikaitkan dengan apa yang disebut "Mandala", sejenis maket kosmos sebagai upaya mengklasifikasi sekaligus pembagian dan penertiban sistem hirarki kerajaan. Konsepsi Mandala merupakan model pembagian kekuasaan yang diatur menurut dua poros besar yang saling memotong secara tegak lurus, yang pada umumnya menghasilkan susunan kekuasaan yang dibingkai dengan lingkaran yang berlapislapis. Pada zaman Mataram, konsep itu berkembang menjadi konsep lingkaranlingkaran konsentris. Di tengah lingkaran paling dalam adalah kekuasaan raja, istana sebagai poros dan merupakan jantung kota. Sementara lapisan di sekelilingnya merupakan wilayah pembungkusnya dengan kekuasaan yang berbeda.

Awal abad ke-19 Raffles mulai menaruh perhatian terhadap topik "indianisasi" dalam upaya mengkaitkan Jawa dengan sistem kekuasaan konsentris atau kuasa "kemaharajaan". Perhatiannya pada tata ruang candi Budhis dan patungpatung dewa agama Hindu terpapar secara luas dalam buku The History of Java, dan naskah-naskah kesusasteraan dari India mulai disadur di Jawa. Ramayana dan Mahabharata merupakan naskah pertama. Setelah Raffles, gagasan indianisasi kemudian dilanjutkan oleh sarjana-sarjana Belanda yang beberapa di antara mereka ahli sansekerta. Huruf-huruf sansekerta inilah kemudian dipelajari untuk menginterpretasikan peninggalanpeninggalan Hindu-Budha yang ditemukan di Jawa, meskipun kandungan filsafatnya tidak begitu banyak.

Perlu disebut pula keterkaitan roda kereta "Singo Barong" dengan ajaran Budhis yang dikenal dengan konsep Cakrawarti (cakkavatti), sebagaimana digambarkan dalam Cakkavatti-sihanada-sutta. Cakrawarti berarti raja dunia, rajadiraja, yang roda-roda keretanya menggelinding tanpa halangan, negaranya membentang dari laut ke laut, di tempat penjuru dunia. la menguasai seluruh dunia yang ditaklukkannya bukan dengan kekerasan atau dengan pedang, melainkan dengan kebenaran (dhamma). Dunia hanya mengenal satu cakrawarti pada satu kurun waktu tertentu, lain dengan raja-raja lokal yang jumlahnya banyak. 
Apa yang disebut cakra permata surgawi akan muncul dengan seribu ruji, roda dan as (poros) serta bagian-bagiannya, ketika seorang cakrawarti memutar roda kewajiban maharaja yang suci. la hidup dalam kebenaran, mensucikan diri dengan kebenaran (Krishnanda, 2003: 487).

\section{KERETA SINGO BARONG DALAM KONTEKS INDUSTRI PARIWISATA}

Digagasnya kereta Singo Barong tersebut tidak lepas dari perkara jaringan sosial yang dibentuk oleh manusia, sebab manusia menghasilkan sejumlah objek material tidak hanya untuk memuaskan diri sendiri atau orang lain tetapi ada keinginan mewujudkan "kebebasan dan kesadaran beraktifitas" untuk mencipta dan menunjukkan bahwa manusia ada dalam "kehidupan produktif" sehingga dia benarbenar menjadi manusia secara individu maupun sosial (Liliweri, 2002). Bila demikian maka kereta "Singo Barong" merupakan representasi dari perilaku sosial manusia, selanjutnya akan memberi pengaruh pula pada tatanan sosial manusia berikutnya.

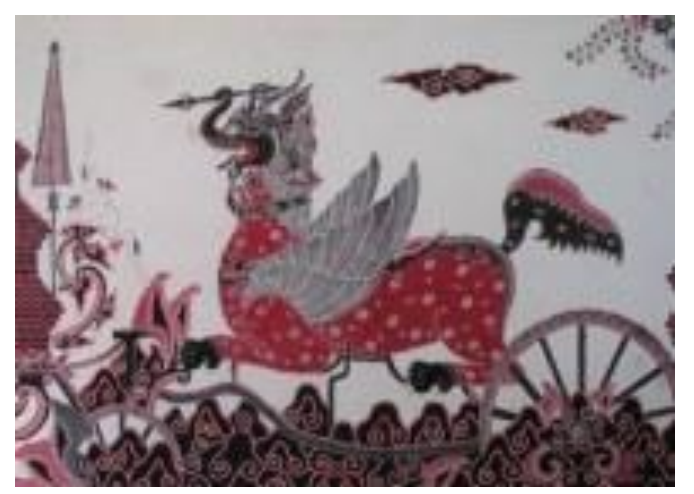

Gambar 4. Batik tulis Cirebon motif Singo Barong sebagai objek material dalam kesadaran beraktifitas

Semenjak keraton Cirebon runtuh, kereta Singo Barong tidak lagi seutuhnya milik keraton akan tetapi milik publik untuk dilestarikan dan dirawat. Bentuk dari kepemilikan dan perawatan tersebut salah satunya adalah memberikan kebebasan kepada masyarakat untuk merefleksikan
Singo Barong ke segala bidang. Selama dua abad lebih, Singa Barong telah diadopsi masyarakat sebagai media gambar atau media komunikasi dalam peningkatan perekonomian, baik melalui usaha di bidang industri batik, lukis kaca, wayang kulit, topeng, wayang golek dan sebagainya, bahkan transportasi kereta api jurusan Jakarta-Cirebon memberikan andil dalam melestarikan batik bertema Singo Barong.

Demikian pengaruh dari kereta Singo Barong di era sekarang meluas hingga melintasi bidang-bidang industri pariwisata, industri sandang, dakwah, transportasi, budaya. Tetapi bila kereta Singo Barong adalah bagian dari eksistensi norma, maka keberadaannya digunakan untuk mengatur standar perilaku masyarakat dalam kehidupan berbudaya dan bermasyarakat. Jadi, yang dipertaruhkan oleh sang pencipta terhadap kereta Singo Barong adalah nilainilai budaya kelompok masyarakat dari kehidupan bermasyarakat. Oleh karena itu kereta Singo Barong dalam ranah budaya merupakan sarana komunikasi dengan masyarakat luas untuk berdialog tentang kekuatan, kekuasaan, kesaktian, kehebatan seniman, ataupun mewakili sekelompok komunitas dalam ruang lingkup sejarah, antropologi, arkeologi, sosiologi,ekonomi ataupun ruang-ruang lain.

Selain memberikan pengaruh terhadap perekonomian, kereta Singo Barong juga memasuki ruang-ruang pariwisata. Bungkusan bunga yang diletakkan di empat sudut kereta Singo Barong merupakan corak lain dari ritual di keraton Kasepuhan Cirebon, sebagai ritual yang menawarkan daya pikat. Ritual yang didasari oleh penawaran daya pikat pada akhirnya melahirkan pemikiran ke arah sektor pariwisata.. Lantaran bunga yang beraroma wangi inilah kesan magis kereta semakin kuat. Sebagian besar pengunjung melihat dari sisi magis tersebut kemudian dengan sadar meletakkan selembar atau dua lembar uang ribuan di atas kereta. 
Maksud dari pengunjung ini tidak sekadar sebagai kontribusi masuk museum melainkan juga merupakan sebuah harapan mendapatkan " berkah" rezeki tetapi bagi penyaji hal ini menjadi media yang bisa menyumbang ekonomi.

Sebagai penyaji (fihak Keraton) sebetulnya berharap terjadinya komunikasi antara penggagas kereta Singo Barong dengan masyarakat agar tidak terlepas dari konteks masa lalu. Tetapi pemahaman terhadap fenomena tersebut tidak seperti yang diharapkan. Tidak saja disebabkan oleh kemajuan pengetahuan masyarakat, tetapi juga disebabkan oleh kultur masyarakat yang seringkali mengkaitkan situs-situs "kramat" terhadap ruang pariwisata, bahkan menjadi kebijakan pariwisata, politik, dan ekonomi wilayah setempat. Kebijakan pemerintah berkaitan dengan penataan ekonomi diarahkan pada kota pelabuhan, kota industri, kota budaya dan kota pariwisata. Hal-hal yang bisa dijadikan objek pariwisata antara lain cagar alam, flora-fauna, benda bersejarah, kesenian rakyat, upacara tradisional dan upacara daur hidup (Yoeti dalam Adeng: 1998).

\section{SIMPULAN}

Salah satu masalah yang dihadapi di abad ke-21 ini adalah perubahan masyarakat yang sangat cepat, terutama kompleksitas perubahan sosial dalam masyarakat modern. Menyikapi persoalan ini, bahwa hidup dalam satu abad, di mana perubahan sosial terjadi secara cepat sudah merupakan hal yang dianggap biasa. Umumnya perubahan sosial inilah yang mengiringi perubahan-perubahan terhadap gagasan, aktivitas, dan artefak. Aktivitas merupakan wujud kebudayaan sebagai suatu tindakan berpola dari manusia dalam masyarakat itu, sedangkan artefak adalah wujud kebudayaan fisik yang dihasilkan dari aktivitas semua manusia dalam masyarakat.

Demikian yang terjadi pada masyarakat Cirebon di masa sekarang dalam memaknai artefak yang kini telah berusia 462 tahun itu. Rentang waktu yang cukup lama itu telah membuat barang seni ini kehilangan "pamor", sebagaimana para raja terdahulu juga mengalami hal yang sama bahwa ketika sudah tidak lagi berkuasa, seluruh atribut kebesaran tinggalah menjadi barang kenangan. Semula atribut kebesaran raja itu bersifat magis, keramat, atau bahkan diyakini sebagai sentral kekuatan alam semesta di wilayah kerajaan, kini berubah menjadi medium seremonial.

Seiring berjalannya ruang dan waktu, dampak sosialnya telah meluas hingga sektor industri dan pariwisata. Wujud atau bentuk dari kereta tersebut telah diadopsi sebagai media gambar atau media komunikasi dalam peningkatan ekonomi, baik melalui usaha di bidang industri batik, lukis kaca, wayang kulit, topeng, wayang golek, hiasan kereta api dan meluas hingga bidang industri pariwisata, industri sandang, dakwah dan transportasi. Sederetan pengusaha-pengusaha batik, seniman-seniman Cirebon, pengrajin kecil, dan budayawan telah ambil bagian atas momentum bersejarah itu.

\section{CATATAN :}

${ }^{1}$ Makhluk Prabangsa adalah gambaran tiga binatang jadi satu, merupakan simbol persahabatan antar bangsa. Belalai Gajah melambangkan persahabatan dengan India, kepala Naga melambangkan persahabatan dengan Cina, Kuda bersayap atau Buroq melambangkan persahabatan dengan Mesir (baca Argadikusuma, "Baluarti Keraton Kesepuhan Cirebon. Perpustakaan Keraton Cirebon., Iqbal "Kafilah Budaya. Pengaruh Persia Terhadap Kebudayaan Indonesi", Jakarta: Citra, 2006).

${ }^{2}$ Seni Kriya memuat pengetahuan yang bisa memberikan pemahaman secara terminologi ataupun bisa menemukan bagaimana kebudayaan berkembang di tengah masyarakat yang tersebar ke seluruh dunia. Tidak saja melihat bagaimana indahnya ukiran ataupun beragamnya corak-corak yang ada, tetapi semua itu terkait dengan realita sosial masyarakat itu sendiri (baca Blakesley "The Art and Crafts Movement", cetak ulang, Phaidon, 2009, hal.6, Gustami "Seni Kerajinan Mebel Ukir Jepara", Kanisius Yogyakarta, 2000, hal. 181-208) 
${ }^{3}$ Maruška Svašek is a graduate of the University of Amsterdam, and has worked for nine years at Queens University Belfast. She has done extensive research and has published widely on the topics of art and politics in Ghana and Czechoslovakia/the Czech Republic, on identity formation and the politics of emotion in the Czech-German border region, and on emotional dynamics and belonging in the context of globalising forces.

${ }^{4}$ Kereta tidak saja menjadi persoalan di zaman Klasik, tetapi kereta juga menjadi perhatian dalam pewayangan. Kereta memiliki posisi dan peran yang penting yakni sebagai kendaraan raja ketika raja tersebut menjadi duta dalam persidanganpersidangan dengan kerajaan lain, ini dilakonkan dalam Kresna Duta (Siswoharsojo,1963: 45). Dalam lakon Kresna Tanding (Radyomardowo, 1959: 109) kereta memiliki posisi kunci untuk menggulingkan kerajaan Astina, dalam ceritera ini kereta dijadikan strategi pihak Pendawa (baca Ki. Siswoharsojo "Sastra Epos Bharata Yuddha.)

${ }^{5}$ Nama kendaraan ini berasal dari nama penemunya, yaitu Charles Theodore Deeleman, seorang litografer dan insinyur pada masa Hindia Belanda. Medali emas diberikan kepada Deeleman atas penemuan "kereta dengan dua roda dan satu kuda dari Batavia" pada pameran Kolonial terbesar pertama dan bersejarah di Amsterdam pada tahun 1883, Hadiahnya 350 gulden bagi C. Deeleman. Pada tahun 1920-an deeleman ini, yang menjadi delman atau dilman dalam perjalanan waktu, sudah sepenuhnya diambil alih, dan menjadi milik rakyat kecil negeri itu. Deeleman menjadi nama akrab di jalanan modern Hindia-Belanda, seperti nama-nama kereta tradisional yang ditarik oleh kuda, sapi, atau kerbau seperti tjikar, gerobak, atau sado. Lambat laun, dan deeleman memimpin banyak tjikar, gerobak, atau sado mulai menggunakan roda karet. Menjelang akhir zaman Belanda, sejumlah deeleman digerakkan oleh motor (baca Rudolf Mrazek, "Engineers of Happy Land. Perkembangan Teknologi dan Nasionalisme di sebuah Koloni“, 2006: 25).

${ }^{6}$ Pembaratan sering dipahami sebagai gaya hidup yang sudah terpengaruh oleh budaya Eropa. Sunan pertama yang menaruh minat akan budaya Barat adalah Amangkurat I. Ketika masih kecil, ia sering mengunjungi tawanan-tawanan Belanda di Keraton ayahnya dan sejak tahun 1659 telah menggunakan kereta buatan Eropa. Amangkurat II dikenal sebagai penggemar busana barat. Dalam kajian menarik mengenai apa yang dianggap sebagai "mahkota mojopahit", H.J. de Graaf menjelaskan bahwa mahkota itu tidak pernah menjadi regalia yang asli, dan bagaimana Belanda dengan maksud menunjukkan bahwa kekuasaan Sunan yang baru itu sesungguhnya berasal dari mereka, menyutradarai sebuah penobatan "cara Eropa" (baca Denys Lombard, "Nusa Jawa: Silang Budaya", 2000, hal. 107108).

\section{DAFTAR PUSTAKA}

Abdullah, Irwan. 2002. Simbol, Makna dan Pandangan Hidup Jawa. Yogyakarta: Balai Kajian Sejarah dan Nilai Tradisional.

Adeng.1998. Kota Dagang Cirebon Sebagai Bandar Jalur Sutra. Jakarta: Direktorat Sejarah dan Nilai Tradisional, Direktorat Jendral Kebudayaan Departemen Pendidikan dan Kebudayaan.

Ahimsa, Heddy Shri. 2002. Tanda, Simbol, Budaya dan Ilmu Budaya. Makalah. Yogyakarta: Fakultas Ilmu Budaya UGM.

Atja. 1986. Carita Purwaka Caruban Nagari. Jawa Barat: Proyek Pengembangan Permuseuman.

Berger, Peter L dan Luckmann Thomas. 1990. Tafsir Sosial Atas Kenyataan; Risalah tentang Sosiologi Pengetahuan. Jakarta : LP3ES.

Budiman, Kris. 2003. Semiotika Visual. Yogyakarta: Yayasan Seni Cemeti.

Frick, Heinz, 1997, Pola Struktural dan teknik Bangunan di Indonesia, Kanisius Yogyakarta.

Geertz, Clifford. 1992 (Cetakan pertama). Tafsir Kebudayaan. Yogyakarta : Kanisius. 
Geertz, Clifford. 2003. Pengetahuan Lokal. Yogyakarta: Merapi.

Hadiwijono, Harun. 1985. Religi Suku Murba di Indonesia. Jakarta: BPK Gunung Mulia.

Iqbal, Muhammad Zafar. 2006. Kafilah Budaya. Pengaruh Persia Terhadap Kebudayaan Indonesia. Jakarta: Citra.

Ivansyah. 2007. "Jejak Budaya Cina di Cirebon". Tempo. Edisi Minggu 16 September 2007. halaman 12-13.

Kartodirdjo, Sartono. 1987. Pengantar Sejarah Indonesia Baru. Jakarta: Gramedia.

Liliweri, Alo. 2002. Makna Budaya dalam Komunikasi Antarbudaya. Yogyakarta: LKIS.

Malinowski, Bronislaw. 1954. Magic, Science and Religion. New York: Doubleday Anchor Books.

Marsidi, Diah. 1995. Pekan Budaya Cirebonan, Jakarta: Bentara Budaya.

Mukti, Krisnanda Wijaya. 2003. Wacana Budha-Dharma. Jakarta: Yayasan Dharma Pembangunan dan Ekayana Buddhis Centre.

Radyomardowo, R.L. 1959. Serat Baratajuda. Yogyakarta: NV. Kedaulatan Rakyat.

Sedyawati, Edi. 1993. Sejarah Kebudayaan Jawa. Jakarta: Departemen Pendidikan dan Kebudayaan Dirjen Kebudayaan Direktorat Sejarah dan Nilai Tradisional Proyek
Inventarisasi dan Dokumentasi Sejarah Nasional.

Siswoharsojo, Ki. 1963. Bharata Yuddha. Ngajogyakarta: Gondolayu DJ. VI/151.

Sulendraningrat, P.S. 1984. Babad Tanah Sunda Babad Cirebon. Cirebon: Perpustakaan Keraton Cirebon.

1972. Purwaka Tjaruban Nagari. Djakarta: Bhratara.

1968. Nokilan Sedjarah Tjirebon Asli. Cetakan ke-2. Pusaka Cirebon.

Tedjoworo, H. 2001. Imaji dan Imajinasi; Suatu Telaah Filsafat Postmodern. Yogyakarta: Kanisius.

Tjokrodipuro, Tt. "Babad Cirebon". Manuskrip Bahasa Sunda huruf Arab. Cirebon: Keraton Cirebon.

Wildan, Dadan. 2003. Perjumpaan Islam dengan Tradisi Sunda. Artikel. Pikiran Rakyat. Rabu 26 Maret 2003.

Yulianti, Rahma. 2008. Menelusuri Jejak Laksamana Cheng Ho. Jakarta. Tabloit Rumah Edisi 129. VI/05 Februari 2008. 